\title{
The Influence of the Agroecological Resources of Crimea on thePrimary and Secondary Metabolites of AligoteGrapes
}

\section{Rybalko Evgeniy, Ostroukhova Elena, Baranova Natalia, Peskova Irina and Borisova Victoria}

Federal State Budget Scientific Institution, «All-Russian National Research Institute of Viticulture and Winemaking «Magarach» of RAS

\section{ORCID}

Rybalko Evgeniy:0000-0002-4579-3505

Corresponding Author: Rybalko

Evgeniy; email:

rybalko_ye_a@mail.ru

Dates

Published 13 January 2022

Publishing services provided by

Knowledge E

(c) Rybalko Evgeniy et al. This article is distributed under the terms of the

Attribution License, which

permits unrestricted use and redistribution provided that the original author and source are credited.

Selection and Peer-review under the responsibility of the 8th Scientific and Practical Conference Conference Committee.
Abstract. This research focused on examining the interrelationships between the natural conditions for growing grapes, as well as the quantitative and qualitative characteristics of the harvest. These are important criteria for the scientifically grounded selection of a territory for planting a vineyard, selecting varieties and determining the use of the resulting products. The characteristics of six model vineyards of the Aligote cultivar, located in various natural zones and viticultural regions of the Crimea, were analyzed. The values of climatic indicators were calculated, including the growing degree days above $10^{\circ} \mathrm{C}\left(\sum \mathrm{T}^{\circ} \mathrm{C}_{10}\right)$, growing degree days above $20^{\circ} \mathrm{C}\left(\sum \mathrm{T}^{\circ} \mathrm{C}_{20}\right)$, Huglin index, Winkler index, average growing season temperature, average September temperature, ratio $\sum \mathrm{T}^{\circ} \mathrm{C}_{20} / \sum \mathrm{T}^{\circ} \mathrm{C}_{10}$,total precipitation during the year, total precipitation during the growing season, total precipitation in September, and Selyaninov hydrothermal coefficient. These were calculated usinggeoinformation and mathematical modeling for the locations of the analyzed vineyards. The content of the primary metabolites (total sugars, titrated acids and calculated indicators based on them) and secondary metabolites (phenolic components, oxidase activity) of grapes from the model vineyards were analyzed. The range of variation in the studied indicators within the analyzed territories was calculated, and the nature and magnitude of the relationships between the indicators were revealed. A cluster analysis of the analyzed vineyards was carried out and clusters were distinguished according to the degree of similarity in climatic parameters, as well as the content of the primary and secondary metabolites of the grapes.

Keywords: grapes, agroecological factors, primary and secondary grape metabolites, ampeloecological zoning, terroir

\section{Introduction}

The study of the impact of agroecological factors on the metabolism of grapes has a deep scientific and practical retrospective. The fundamental aspects of such studies are aimed at preserving and expanding the biological diversity of ampelosystems, identifying genetic specificity, adaptive plasticity of grape cultivars, etc. [1-4]. Revealing the relationship between the natural conditions of growing grape and the quantitative 
and qualitative characteristics of the harvest and wine production is necessary to achieve national economic goals: the scientific choice of the territory for planting a vineyard, the selection of cultivars and the determination of the direction of use of the resulting products (specialization of winemaking) [5]. Global climate change associated with an increase in the average ambient temperature, an increase in the difference between summer and winter temperatures, a destruction of the water balance, introduces significant adjustments to the metabolism of grapes, as a result of which the vegetative cycle of the plant is disrupted, the established agrobiological and technological characteristics of grapes change $[6,7]$. The above makes the study of agroecological resources as factors that form the primary and secondary metabolites of grapes and the object-oriented assessment of territories for its cultivation, especially relevant.

The problematic task of research in this direction is to determine the exact mesoclimatic characteristics of the analyzed grape growing areas, since they can differ significantly from the conditions at the nearest meteorological station, taken as the basis for obtaining climatic information. For this, various methods of data collection and processing are used, including remote sensing methods [8, 9]. A promising solution to this issue is geoinformation and mathematical modeling of the spatial variation of climatic indicators under the influence of orographic, hydrological and geographical parameters of the analyzed territories, which, however, is currently very limitedly used for zoning ampeloterritories [10-14].

The second important task is the selection of the most informative climatic indicators, the range of which is constantly expanding. So, in Russia, European countries,USA and Australiathe spatial and temporal variability of various climatic indices affecting grapes is studied with the aim of ampeloecological zoning of territories: Winkler's index, Huglin solar thermal index, average temperature during the growing season, growing degree days, biologically effective degree days, etc. [15-21].

Expansion of the taken into account quality characteristics of grapes and wine products is relevant in assessing the ampeloecological resources of geographic objects. The approach to the ampeloecological zoning of territories that has existed for decades on the basis of the fundamental possibility of growing grapes, the size of the yield and the basic indicators of its quality (the concentration of sugars and titratable acids) does not correspond to the modern achievements of world science and practice of winemaking. Numerous studies indicate that the quality of grapes and wine is due to a wide range of parameters, including the activity of native enzymes, the quantitative content and qualitative composition of phenolic, aroma-forming complexes, organic acids, etc., which 


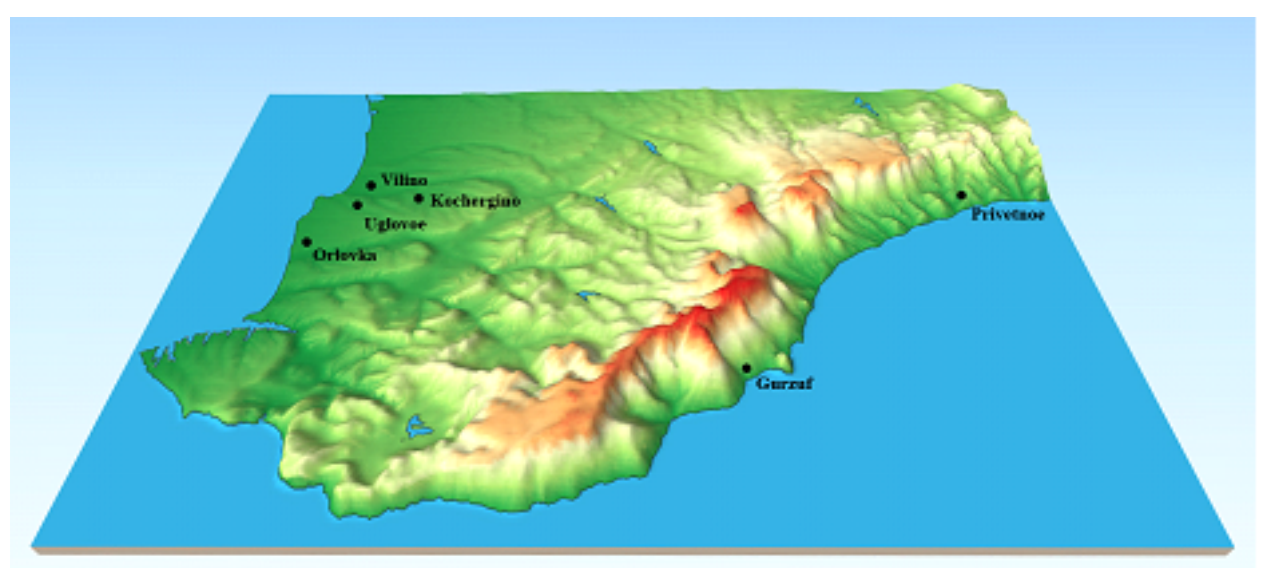

Figure 1: The location of the analyzed vineyards on the Crimea.

largely depend on both the natural conditions of plant growth and the grape cultivars [22].

Thus, a reliable study and zoning of the ampeloecological resources of territories is possible only with a systematic approach, including the identification and geoinformation modeling of multiparameter relationships of the spatial distribution of agroecological characteristics and metabolites of grapes (taking into account the variety specificity), the quality of the harvest and wine production. The first stage of these studies is the present work aimed at studying agroecological resources in the Aligote vineyards located on the Crimea, and their influence on the formation of the primary and secondary metabolites of grapes.

\section{Materials and methods}

\subsection{Vineyards}

The study of agroecological parameters was carried out in 6 industrial vineyards (Aligote cultivar) of the Crimea. Vineyards are located in geographical objects (Figure 1): Vilino village (hereinafter also used the digital designation of vineyards -1 ), Kochergino village (2), Orlovka village (3), Uglovoe village (4) in the western foothill-coastal region; Gurzuf urban village (5) in the south coast region and Privetnoe village (6) in the mountainvalley coastal region of the South Coast zone [23]. Agricultural technology system of the vineyards is in accordance with the technological map adopted for each cultivar in the area. 


\subsection{Agroecological parameters of vineyards and methods for their determination}

For each vineyard, the following agroecological parameters were determined: growing degree days above $10{ }^{\circ} \mathrm{C}\left(\sum \mathrm{T}^{\circ} \mathrm{C}_{10}\right)$, growing degree days above $20{ }^{\circ} \mathrm{C}\left(\sum \mathrm{T}^{\circ} \mathrm{C}_{20}\right)$, Huglin index, Winkler index, average growing season temperature, average September temperature, ratio $\sum \mathrm{T}^{\circ} \mathrm{C}_{20} / \sum \mathrm{T}^{\circ} \mathrm{C}_{10}$, total precipitation during the year, total precipitation during the growing season, total precipitation in September, Selyaninov hydrothermal coefficient (HTC), which is the ratio of the total precipitation during the growing season period increased by 10 times togrowing degree days above $10^{\circ} \mathrm{C}[20,24-26]$.

To calculate agroecological indicators at the points of location of the analyzed vineyards, the geographical coordinates of the vineyards, morphometric features of the relief (absolute height above sea level, steepness and aspect of the slope, relative elevation over thalweg), soil cover characteristics, as well as the nearest stationary meteorological station were determined. The calculation of the value of each of the analyzed climatic factors at the location of the vineyards was carried out by the method of geoinformation modeling using long-term data from the network of stationary weather stations of the Crimea for 1985-2019, digital elevation models SRTM-3 and ASTER GDEM, the global climate model Worldclim ver. 2.0 and mathematical models developed by the authors describing the patterns of spatial variation of climatic indicators under the influence of orographic, hydrological and geographical parameters of the analyzed territory [27-30].

\subsection{Grape samples and analysis methods}

Aligote cultivar of 2013-2019 harvest were analysed. The sampling of grapes was carried out in the vineyards when they reached technical maturity during the industrial harvest. Samples were transported immediately under refrigeration $\left(2-5{ }^{\circ} \mathrm{C}\right)$ to the laboratory for analysis.

To analyze grapes $500-600 \mathrm{~g}$ of the berries of each sample were crushed in a turbo blender (Moulinex-LM600E, France) during 2 min.

To determine the technological reserve of phenolic compounds (TRPh) the resulting pomace was heated and kept in the thermostat at $70{ }^{\circ} \mathrm{C}$ for 30 minutes with stirring. After pomace cooling, we separated the must and measured concentration of phenolic compounds with Folin-Ciocalteu reagent [31]. Technological reserve of phenolic compounds is that part of them that can transfer to the must during red winemaking. We calculated the degree of phenolic components'transition into must in the process of 
whole berry pressing $\left(\mathrm{Ph}_{0} / \mathrm{TRPh}\right)$ and 4-hour mash maceration fromtheir technological reserve $\left(\mathrm{Ph}_{4} / \mathrm{TRPh}\right)$.

The juice suspension was centrifuged at $5000 \mathrm{rpm}$ for $15 \mathrm{~min}$ at room temperature to get a clarified juice to determine the content of total sugars in grapes, titrated acids, active acidity $(\mathrm{pH})$. The juice was then filtered through $0.45 \mu \mathrm{m}$ pore size membrane filters and incubated at $20{ }^{\circ} \mathrm{C}$ for analysis. Total sugars were determined using the aerometric method, titrated acids in terms of tartaric acid were determined by the titrimetric method [32]. Gluco-acidimetric index (GAl) and grape ripeness index (RI = Brix $x \mathrm{pH}^{2}$ ) were calculated. The monophenolmonooxidase activity of wort (AMPhMO, item) was determined by the rate of oxidation of a pyrocatechol solution [33].

\subsection{Statistical analysis of the data}

The total number of grape samples was 32. All assays were performed in 2-3 replications. Experimental material was processed by variance (ANOVA), discriminative and cluster analysis methods (using Statistics 10 program). Normality of distribution was assessed by Kolmogorov-Smirnov test. Value comparison of quantitative attributes in independent subgroups was performed using either Student's t-test (for normally distributed attributes) or the Mann-Whitney U-test. Verification of statistical coefficients was performed for significance point of a $<0.05$. Information value of discriminant variables was assessed based on Wilks statistics.

\section{Results and discussion}

The values of the climatic indicators of the analyzed Aligote vineyards (for each and for all), obtained by nonlinear interpolation of long-term observations at the Crimean weather stations using the methods of geoinformation and mathematical modeling, are given in Table 1.The presented data demonstrate a moderate range of variation in the parameters of heat and moisture supply in vineyards. At the same time, the geographical location of vineyards is a significant factor in the dispersion of the studied climatic parameters. For most parameters, the level of significance of differences for vineyards is $\alpha<0.000001$, for $\mathrm{HTC}-\alpha<0.0001$, for Huglin index and $\sum \mathrm{T}^{\circ} \mathrm{C}_{20} / \sum \mathrm{T}^{\circ} \mathrm{C}_{10^{-}}$ $\alpha<0.05$. The amount of precipitation falling on the vineyards in September varied from 0.0 to $156.6 \mathrm{~mm}$, regardless of the geographical location of the vineyards. The highest values (6-26\% higher than the average values for all vineyards) of heat supply indicators were characteristic of the vineyards of Gurzuf urban village and Orlovka village. At the 
TABLE 1: Values* of climatic parameters of Aligote vineyards located in different geographical objects.

\begin{tabular}{|c|c|c|c|c|c|c|c|}
\hline \multirow[t]{4}{*}{ Index } & \multicolumn{6}{|c|}{ Natural zone / viticulture area / geographical location (vineyard number) } & \multirow[t]{4}{*}{ All vineyards } \\
\hline & \multicolumn{4}{|c|}{ Foothill zone } & \multicolumn{2}{|c|}{ South coast zone } & \\
\hline & \multicolumn{4}{|c|}{ Western foothill-seaside area } & \multirow{2}{*}{$\begin{array}{l}\text { South coast area } \\
\text { Gurzufurban } \\
\text { v.(5) }\end{array}$} & \multirow{2}{*}{$\begin{array}{l}\text { Mountain-valley } \\
\text { seasidearea } \\
\text { Privetnoev. (6) }\end{array}$} & \\
\hline & Villino v. (1) & Kochergino v. (2) & Orlovka v. (3) & Uglovoe v. (4) & & & \\
\hline $\begin{array}{l}\text { Growing degree } \\
\text { days } \sum \mathrm{T}^{\circ} \mathrm{C}_{10},{ }^{\circ} \mathrm{C}\end{array}$ & $\frac{3529 \pm 314}{2682-4114}$ & $\frac{3438 \pm 314}{2590-4023}$ & $\frac{3926 \pm 253}{3559-4430}$ & $\frac{3447 \pm 314}{2600-4032}$ & $\frac{4207 \pm 328}{3705-4861}$ & $\frac{3760 \pm 496}{2809-4710}$ & $\frac{3677 \pm 435}{2591-4861}$ \\
\hline $\begin{array}{l}\text { Growing degree } \\
\text { days } \sum \mathrm{T}^{\circ} \mathrm{C}_{20},{ }^{\circ \mathrm{C}}\end{array}$ & $\frac{1715 \pm 470}{647-2813}$ & $\frac{1643 \pm 470}{539-2705}$ & $\frac{2212 \pm 378}{1593-2797}$ & $\frac{1671 \pm 470}{567-2733}$ & $\frac{2408 \pm 456}{1546-3057}$ & $\frac{1993 \pm 588}{988-3183}$ & $\frac{1904 \pm 547}{539-3183}$ \\
\hline Huglin index & $\frac{2519 \pm 258}{1931-2967}$ & $\frac{2487 \pm 258}{1899-2935}$ & $\frac{2410 \pm 494}{268-2822}$ & $\frac{2488 \pm 258}{1900-2936}$ & $\frac{2715 \pm 189}{2341-2987}$ & $\frac{2464 \pm 280}{1894-3021}$ & $\frac{2508 \pm 305}{268-3021}$ \\
\hline Winkler index & $\frac{1585 \pm 202}{1093-2072}$ & $\frac{1542 \pm 202}{1050-2029}$ & $\frac{1799 \pm 144}{1551-2148}$ & $\frac{1547 \pm 202}{1055-2034}$ & $\frac{1998 \pm 189}{1622-2350}$ & $\frac{1729 \pm 288}{1181-2346}$ & $\frac{1677 \pm 260}{1050-2350}$ \\
\hline $\begin{array}{l}\text { Average } \\
\text { September } \\
\text { temperature, } \\
{ }^{\circ} \mathrm{C}\end{array}$ & $\frac{16.6 \pm 2.0}{10.2-20.7}$ & $\frac{16.0 \pm 2.0}{9.6-20.1}$ & $\frac{19.6 \pm 1.2}{17.1-22.6}$ & $\frac{16.2 \pm 2.0}{9.8-20.3}$ & $\frac{18.9 \pm 2.1}{11.3-22.1}$ & $\frac{17.9- \pm 2.2}{10.7-22.4}$ & $\frac{17.3 \pm 2.3}{9.6-22.6}$ \\
\hline $\begin{array}{l}\text { Average } \\
\text { growing season } \\
\text { temperature, }{ }^{\circ} \mathrm{C}\end{array}$ & $\frac{18.3 \pm 1.0}{16.4-20.4}$ & $\frac{18.2 \pm 1.0}{16.3-20.3}$ & $\frac{19.2 \pm 0.8}{17.9-20.5}$ & $\frac{18.2 \pm 1.0}{16.3-20.3}$ & $\frac{19.8 \pm 1.0}{17.8-21.3}$ & $\frac{18.8 \pm 1.4}{16.3-21.7}$ & $\frac{18.7 \pm 1.2}{16.3-21.7}$ \\
\hline$\sum \mathrm{T}^{\circ} \mathrm{C}_{20} / \Sigma \mathrm{T}^{\circ} \mathrm{C}_{10}$ & $\frac{0.49 \pm 0.11}{0.19-0.75}$ & $\frac{0.47 \pm 0.11}{0.17-0.74}$ & $\frac{0.56 \pm 0.09}{0.40-0.71}$ & $\frac{0.48 \pm 0.11}{0.17-0.74}$ & $\frac{0.57 \pm 0.10}{0.36-0.77}$ & $\frac{0.52 \pm 0.11}{0.33-0.77}$ & $\frac{0.51 \pm 0.11}{0.17-0.77}$ \\
\hline HTC & $\frac{0.74 \pm 0.26}{0.39-1.49}$ & $\frac{0.80 \pm 0.26}{0.45-1.6}$ & $\frac{0.52 \pm 0.17}{0.22-0.92}$ & $\frac{0.76 \pm 0.26}{0.41-1.51}$ & $\frac{0.81 \pm 0.18}{0.48-1.28}$ & $\frac{0.64 \pm 0.20}{0.35-1.15}$ & $\frac{0.72 \pm 0.24}{0.22-1.55}$ \\
\hline $\begin{array}{l}\text { Total precipitation } \\
\text { during the year, } M M\end{array}$ & $\frac{464 \pm 101}{329-728}$ & $\frac{490 \pm 108}{352-777}$ & $\frac{590 \pm 0 J}{263-607}$ & $\frac{413 \pm 105}{337-744}$ & $398-1033$ & $\frac{458-643}{278-6}$ & $263-1033$ \\
\hline $\begin{array}{l}\text { Total precipitation } \\
\text { during the growing } \\
\text { season, } M M\end{array}$ & $\frac{248 \pm 70}{142-469}$ & $\frac{268 \pm 76}{154-508}$ & $\frac{206 \pm 73}{79-386}$ & $\frac{250 \pm 71}{144-475}$ & $\frac{341 \pm 86}{181-515}$ & $\frac{233 \pm 78}{128-420}$ & $\frac{256 \pm 83}{79-515}$ \\
\hline $\begin{array}{l}\text { Total precipitation } \\
\text { in September, } \mathrm{mm}\end{array}$ & $\frac{37.3 \pm 32.6}{0.0-144.4}$ & $\frac{39.4 \pm 34.4}{0.0-152.3}$ & $\frac{43.6 \pm 37.1}{1.1-142.1}$ & $\frac{38.6 \pm 33.7}{0.0-149.2}$ & $\frac{59.3 \pm 48.3}{0.5-156.6}$ & $\frac{32.2 \pm 32.4}{0.0-129.8}$ & $\frac{40.6 \pm 36.4}{0.0-156.6}$ \\
\hline
\end{tabular}

same time, the Gurzuf vineyard was distinguished by the highest moisture supply, the values of which were $13-35 \%$ higher than the average values for all vineyards. On the contrary, the Orlovka vineyard was characterized by the HTC value by $22 \%$ less than the average value of the parameter for all vineyards, and by the annual precipitation by $18 \%$.

The results of the hierarchical classification of long-term climatic data showed that vineyards of Kochergino, Uglovoe and Vilino are the closest in all climatic parameters -the standardized Euclidean distance (Ed) is 0.40-0.76 (Figure 2)-and belong to the same cluster (I). By heat supply, vineyards of Orlovka and Gurzuf form a separate cluster (II) - Ed between them is 2.95 and their distance from other vineyards is 4.22-5.51. In terms of moisture supply, a separate cluster (III) includes vineyards of Orlovka and Greetings ( $E d=1.11$ ), distant from other vineyards at $E d=2.95-4.27$. In Figure $2 A$ clearly shows the best result $(\alpha<0.00001)$ of discriminating the identified vineyard clusters in terms of heat supply, which was obtained with the aggregate consideration of the parameters: $\Sigma \mathrm{T}^{\circ} \mathrm{C}_{10}$, Huglin index and Winkler index. Increasing the values of these parameters in the diagrams in Figure 2 is indicated by arrows. As can be seen from the diagram of Privetnoye village occupies an intermediate position between the two clusters in terms of heat supply. The most significant parameters of moisture supply in discriminating vineyards were the HTC, the amount of annual precipitation and precipitation during the growing season. Their aggregate accounting discriminated 

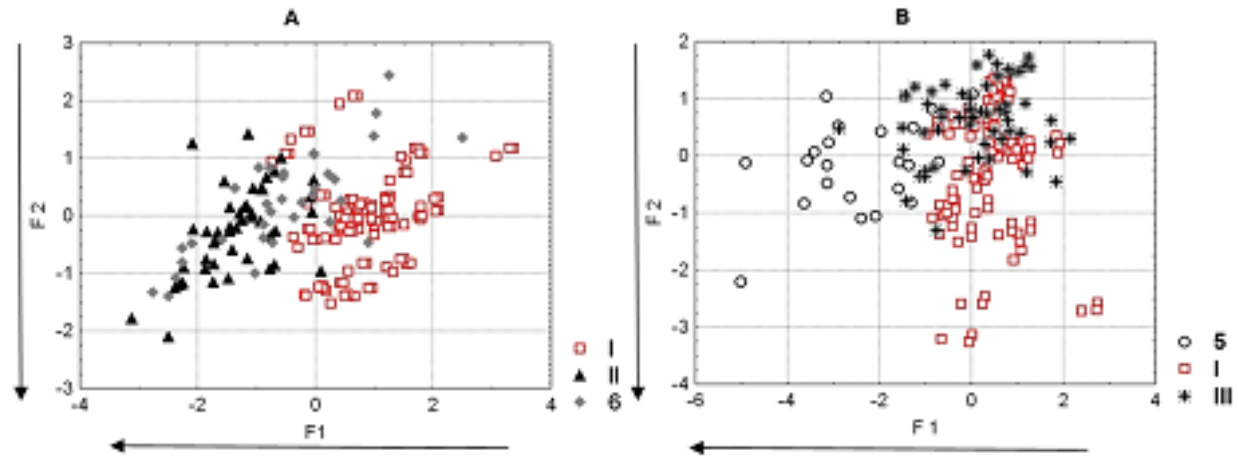

Figure 2: Diagram reflecting the differences in heat supply $(A)$ and moisture supply $(B)$ in vineyards: I cluster: Vilino + Kochergino + Uglovoe; II - cluster: Orlovka + Gurzuf; III -cluster: Orlovka + Privetnoe; vineyards: 5 - Gurzuf, 6- Privetnoe.

against the identified clusters of vineyards at a significance level of $\alpha<0.00001$. The Gurzuf vineyard significantly exceeds the rest of the vineyards and is not included in any cluster. It should be noted the high (0.35-0.44) statistics of Wilks L. when discriminating vineyards by climatic parameters. This indicates that the analysis did not consider important factors, one of which is the year of observation (harvest).

The harvest year is a significant factor in the dispersion of all climatic parameters of vineyards at $\alpha<0.000001$. A consistent increase in the values of heat supply in vineyards over the years of observations was revealed, which is consistent with the trends in climate change according to geographically averaged data from all weather stations of the Crimea [34]. Compared to 1985-1994, in 2015-2019 the average values of $\sum \mathrm{T}^{\circ} \mathrm{C}_{10}$ increased $(\alpha<0.000001)$ by $22 \%, \sum \mathrm{T}^{\circ} \mathrm{C}_{20}-$ by $80 \%$, Huglin index-by $25 \%$, Winkler index - by $36 \%$, the average September temperature -by $26 \%$, the average temperature during the growing season - by $14 \%$. The ratio $\sum \mathrm{T}^{\circ} \mathrm{C}_{20} / \sum \mathrm{T}^{\circ} \mathrm{C}_{10}$ for the same period increased by 1.5 times. At the same time, the relative increase in the amount of annual precipitation was $16 \%$, the amount of precipitation during the growing season was $22 \%$; the value of the HTC practically did not change, and the amount of precipitation in September decreased by $26 \%$. The presented data clearly demonstrate the change in climatic parameters in the analyzed vineyards, which cannot but affect the plant metabolism.

Table 2 shows the values of some primary (total sugars, titrated acids, calculated indicators based on them) and secondary (phenolic components, oxidase activity) metabolites of Aligote grape of 2013-2019 harvest obtained from the investigated vineyards. Analysis of the data shows that the sugar content in berries varied in the range from 167 $\mathrm{mg} / \mathrm{dm}^{3}$ to $234 \mathrm{~g} / \mathrm{dm}^{3}$ and did not differ significantly depending on the geographical location of the vineyards. The latter is explained by the fact that the grape samples were taken during the industrial harvest. The exception was grapes from Gurzuf, in which the 
TABLE 2: Values* of physicochemical and biochemical parameters of grapes of 2013-2019 harvest, obtained in different vineyards.

\begin{tabular}{|c|c|c|c|c|c|c|c|}
\hline \multirow[t]{4}{*}{ Index } & \multicolumn{6}{|c|}{ Natural zone / viticulture area / geographical location (vineyard number) } & \multirow[t]{3}{*}{ All vineyards } \\
\hline & \multicolumn{4}{|c|}{ Foothill zone } & \multicolumn{2}{|c|}{ South coast zone } & \\
\hline & \multicolumn{4}{|c|}{ Western foothill-seaside area } & \multirow{2}{*}{$\begin{array}{l}\text { South coast area } \\
\text { Gurzufurban } \\
\text { v.(5) }\end{array}$} & \multirow{2}{*}{$\begin{array}{l}\text { Mountain-valley } \\
\text { seasidearea } \\
\text { Privetnoev.(6) }\end{array}$} & \\
\hline & Villino v. (1) & $\begin{array}{l}\text { Kochergino v. } \\
\text { (2) }\end{array}$ & Orlovka v.(3) & Uglovoe v. (4) & & & \\
\hline $\begin{array}{l}\text { Total sugars } \\
\mathrm{g} / \mathrm{dm}^{3}\end{array}$ & $\frac{208 \pm 22}{180-234}$ & $\frac{199 \pm 18}{180-220}$ & $\frac{183 \pm 14}{164-196}$ & $\frac{190 \pm 16}{167-218}$ & $\frac{228 \pm 15}{193-239}$ & $\frac{200 \pm 6}{196-204}$ & $\frac{197 \pm 19}{167-234}$ \\
\hline $\begin{array}{l}\text { Titrated acids, } \\
\mathrm{g} / \mathrm{dm}^{3}\end{array}$ & $\frac{5.7 \pm 0.9}{4.7-6.8}$ & $\frac{7.6 \pm 0.6}{6.8-8.0}$ & $\frac{6.9 \pm 1.6}{5.8-9.3}$ & $\frac{6.7 \pm 1.2}{5.6-8.5}$ & $\frac{5.0 \pm 0.8}{4.3-6.0}$ & $\frac{7.5 \pm 0.3}{7.3-7.7}$ & $\frac{6.5 \pm 1.3}{4.7-9.3}$ \\
\hline $\begin{array}{l}\text { Active acidity } \\
(\mathrm{pH})\end{array}$ & $\frac{3.22 \pm 0.28}{2.80-3.60}$ & $\frac{3.30 \pm 0.13}{3.10-3.49}$ & $\frac{3.24 \pm 0.09}{3.19-3.35}$ & $\frac{3.19 \pm 0.12}{3.03-3.34}$ & $\frac{3.40 \pm 0.12}{3.28-3.53}$ & $\frac{3.24 \pm 0.15}{3.13-3.34}$ & $\frac{3.23 \pm 0.17}{2.80-3.60}$ \\
\hline $\begin{array}{l}\text { Gluco- } \\
\text { acidimetric } \\
\text { index (GAl) }\end{array}$ & $\frac{3.7 \pm 0.9}{2.6-5.0}$ & $\frac{2.6 \pm 0.5}{1.8-3.0}$ & $\frac{2.8 \pm 0.7}{1.8-3.2}$ & $\frac{2.9 \pm 0.5}{2.2-3.6}$ & $\frac{4.6 \pm 0.6}{2.8-5.0}$ & $\frac{2.7 \pm 0.2}{2.5-2.8}$ & $\frac{3.1 \pm 0.8}{1.8-5.0}$ \\
\hline $\begin{array}{l}\text { Grape } \\
\text { ripeness } \\
\text { index (RI) }\end{array}$ & $\frac{220 \pm 59}{146-303}$ & $\frac{217 \pm 34}{185-264}$ & $\frac{192 \pm 19}{176-220}$ & $\frac{193 \pm 19}{167-217}$ & $\frac{264 \pm 12}{248-277}$ & $\frac{209 \pm 13}{200-217}$ & $\frac{206 \pm 37}{146-303}$ \\
\hline $\begin{array}{l}\mathrm{TRPh}, \\
\mathrm{mg} / \mathrm{dm}^{3}\end{array}$ & $\frac{695 \pm 330}{323-1127}$ & $\frac{1096 \pm 146}{855-1167}$ & $\frac{932 \pm 48}{891-999}$ & $\frac{953 \pm 238}{612-1272}$ & $\frac{620 \pm 152}{469-782}$ & $\frac{893 \pm 156}{772-1156}$ & $\frac{855 \pm 253}{323-1272}$ \\
\hline $\mathrm{Ph}_{0} / \mathrm{TRPh}, \%$ & $\frac{72 \pm 23}{46-92}$ & $\frac{39 \pm 13}{22-51}$ & $\frac{32 \pm 8}{25-40}$ & $\frac{38 \pm 7}{29-45}$ & $\frac{64 \pm 18}{45-81}$ & $\frac{39 \pm 17}{21-64}$ & $\frac{44 \pm 18}{25-92}$ \\
\hline $\left.\mathrm{Ph}_{4} / \mathrm{TRPh}, \%\right)$ & $\frac{65 \pm 16}{55-83}$ & $\frac{27 \pm 10}{18-44}$ & $\frac{39 \pm 5}{36-45}$ & $\frac{37 \pm 11}{27-52}$ & $\frac{45 \pm 12}{35-61}$ & $\frac{41 \pm 15}{29-60}$ & $\frac{45 \pm 18}{27-84}$ \\
\hline $\begin{array}{l}\mathrm{A}_{M P h M O} \times 10^{2}, \\
\text { item }\end{array}$ & $\frac{12.1 \pm 5.2}{6.2-20.8}$ & $\frac{8.1 \pm 0.8}{7.4-10.3}$ & $\frac{10.4 \pm 6.5}{02-15.6}$ & $\frac{14.0 \pm 11.1}{4.6-34.5}$ & $\frac{15.3 \pm 10.2}{5.0-30.1}$ & $\frac{8.7 \pm 0.9}{7.5-9.7}$ & $\frac{12.1 \pm 7.7}{2.0-34.5}$ \\
\hline
\end{tabular}

sugar content was on average $16 \%$ higher than the value of the indicator in berries obtained in other geographical areas. The concentration of titratable acids in grapes averaged $6.5 \pm 1.3 \mathrm{~g} / \mathrm{dm}^{3}$. In the grapes obtained in Kochergino and Privetnoe, the value of the indicator exceeded the average by $17 \%$, in the grapes from Gurzuf, on the contrary, the value was $23 \%$ less. Accordingly, the grapes from Gurzuf was characterized by the highest gluco-acidimetric index (GAl - 1.5 times higher than the average for vineyards), grape ripeness index (RI -1.3 times) and $\mathrm{pH}$ (by 0.17 units). Differences of Gurzuf grapes in terms of the content of the main metabolites is consistent with the highest heat and moisture supply in the vineyard (see Table 1). It is known that the temperature factor affects the intensity of photosynthesis, the migration of nutrients in the plant: a temperature above $20{ }^{\circ} \mathrm{C}$ is most favorable for the growth of shoots, the accumulation of sugars and a decrease in the concentration of titratable acids during the ripening of grapes [35-37]. Cluster analysis confirmed the difference between the grapes from Gurzuf from the harvest from other vineyards in terms of the content of the main metabolites, $\mathrm{GAI}, \mathrm{RI}$ and $\mathrm{pH}$ : $\mathrm{Ed}=3.29-5.03$. The similarity / difference of the analyzed indicators of the composition and properties of grapes from other geographic objects was characterized by Ed $=1.34-2.72$ (Figure3A).

High moisture availability and low temperature in September prevent the accumulation of phenolic components in grapes [1;37-39], which is reflected in the value of the technological stock of components in Aligote grapes form Gurzuf and Vilino, 

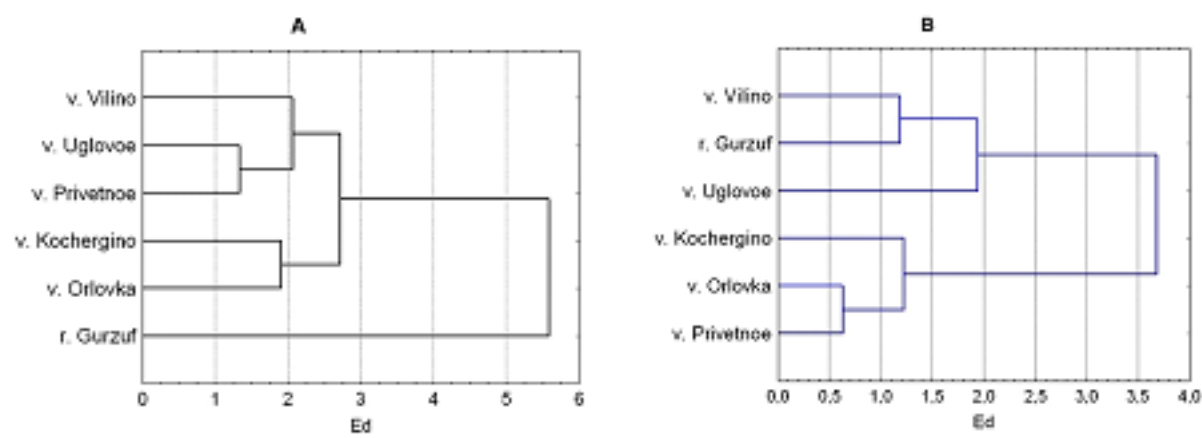

Figure 3: The result of vineyard clustering by a set of indicators of carbohydrate-acid (A), phenolic and oxidase (B) grape complexes.

which is on average $32 \%$ less than the values of the indicator for grapes obtained in other geographical objects. Grapes from Gurzuf and Vilino was characterized by a high degree of transfer of phenolic substances from the solid parts of the berry to the wort, both by pressing the berries and during 4 hours of infusion of the must $(64-72 \%$ and $45-65 \%$ of the technological reserve of phenolic substances, respectively). During berries pressing, this is due to the permeability of the secondary cell walls of the skin and is interrelated with the accumulation of sugars [40]. With 4-hour infusion of the must, the formation of the phenolic complex of the wort is the result of two oppositely directed processes: the extraction of components and their oxidative transformation [41; 42]. The lowest oxidase activity of the must was observed for grapes from Kochergino and Privetnoe ( $30 \%$ lower than the average for all vineyards), the largest - grapes from Gurzuf (26\% higher), which, as our earlier studies showed, is interconnected with the heat supply of vineyards [37]. According to the totality of indicators of phenolic and oxidase complexes, grapes from Vilino and Gurzuf form a cluster characterizing Ed = 1.19; the second cluster is made up of vineyards from Kochergino, Orlovka and Privetnoe $(\mathrm{Ed}=0.63-1.23)$ (Figure 3B).

\section{Conclusion}

As a result of the research, several relationships have been revealed between the climatic parameters of vineyards and the content of primary and secondary metabolites in Aligote grapes. The scope was established in various natural zones and natural viticultural regions of the Crimea. The data obtained are the basis for the creation of multi-parameter geoinformation models of the spatial distribution of ampeloecological resources and a scientifically grounded methodology for the selection of object-oriented terroirs with exceptional agroecological potential, allowing to grow grapes to obtain wine products that are unique in their characteristics. 
The work is aimed at development of winemaking with geographical status in the Russian Federation, enhancing the image and competitiveness of wines.

\section{Acknowledgments}

The authors are grateful to Junior Staff Scientists Zaitseva O., Lutkova N., Belash D. for performing physicochemical analyzes and participation in the preparation of the publication.

\section{Conflict of Interest}

The authors declare no conflict of interest.

\section{References}

[1] Downey MO, Dokoozlian NK, Krstic M. Cultural, practice and environmental impacts on the flavonoid composition of grapes and wine: A review of recent research. American Journal of Enology and Viticulture.2006;57(3):257-268.

[2] Ubalde JM, Sort X, Poch RM, Porta M.Influence of edapho-climatic factors on grape quality in Conca de Barberà Vineyards (Catalonia, Spain). Journal International Des Sciences De La Vigne Et Du Vin. 2007;1:33-41.

[3]

[3] Van Leeuwen C, Darriet P. (2016). The impact of climate change on viticulture and wine quality. Journal of Wine Economics. 2016;1:150-167.

[4] Drappier J, Thibon C, Rabot A, Geny-DenisL. Relationship between wine composition and temperature: Impact on Bordeaux wine typicity in the context of global warming. Review, Critical Reviews in Food Science and Nutrition.2019;59(1):14-30. doi: 10.1080/10408398.2017.1355776

[5] Foursa DI, Foursa VP.Effects of climatic peculiarities of the south coast of the Crimea on the specialization of the grape and wine industry of the region. Works of Scientific Center of Viticilture and Winemaking of Yalta National Instituta of Viticulture and Winemaking. 2001;3:15-21.

[6] Jones G. Climate change: Observations, projections, and general implications for viticulture and wine production. Practical Winery and Viticulture. 2007; 1(29).55-66 
[7] Jarvis C, Barlow E, Darbyshire R, Eckard R, Goodwin I. (2017). Relationship between viticultural climatic indices and grape maturity in Australia. International Journal of Biometeorology. 2017;61(10):1849-1862.

[8] Rybalko EA, Baranova NV, Loupian E?et al. (2016). Management of ground and remote sensing data for remote monitoring of vineyards. Current Problems in Remote Sensing of the Earth From Space.2016;13:79-92.

[9] Tolpin VA, Rybalko EA, Baranova NV, Kashnitskii AV, Loupian EA, Uvarov IA. Building a repository of satellite and ground data for the development of viticulture remote monitoring methods in the Republic of Crimea. Current Problems in Remote Sensing of the Earth From Space. 2017;14:101-110.

[10] Liviu M, Irimia L, Patriche CV, Quenol H.Viticultural zoning: A comparative study regarding the accuracy of different approaches in vineyards climate suitability assessment. Cercetari Agronomice in Moldova. 2013;46(3):95-106.

[11] Irimia L, Patriche CV, Quenol H.(2012). Mapping viticultural potential in temperate climate areas. Case study: Bucium vineyard (Romania). Cercetari Agronomice în Moldova. 2012;2(150):75-84.

[12] Schultze SR,Sabbatini P,Andresen JA.(2014). Spatial and temporal study of climatic variability on grape production in southwestern Michigan. American Journal of Enology and Viticulture. 2014;65(2):179-188.

[13] Jones NK.An investigation of trends in viticultural climatic indices in Southern Quebec, a cool climate wine region.Journal of Wine Research. 2018;29(2-3):120129.

[14] van Leeuwen C, Bois B. Update in unified terroir zoning methodologies. Presented at:E3S Web of Conferences 50, 01044 (2018) XII Congreso Internacional Terroir. Aragon, Spain, June 18-22, 2018

[15] Naumova LG, Novikova LY.Thermal analysis of interphase periods of grapes collection of All-Russian Research Institute of Viticulture and Winemaking named after Y.I. Potapenko.Viticulture and Winemaking. 2015;5:46-50.

[16] Egorov ??, Petrov VS. Creation of the sustainable self-regulating grapes agrocenoses in the temperate continental climate conditions of the Russian's south.Bulletin of the Russian Agricultural Science. 2017;5:51-54.

[17] Jones GV, Duff AA, Hall A, Myers JW. Spatial analysis of climate in winegrape growing regions in the western United States. American Journal of Enology and Viticulture. 2010;61:313-326.

[18] Kryza M, Szymanowski M, Blas M, Migala K, Werner M, Sobik M. Observed changes in SAT and GDD and the climatological suitability of the Poland-Germany-Czech 
Republic transboundary region for wine grapes cultivation. Theoretical and Applied Climatology. 2015;122(1-2):207-218.

[19] ComteV, Zufferey V,Rösti J, CalancaP, RebetezM.Adaptation strategies of a cold climate vineyard to climate change, the case of the Neuchâtel region in Switzerland. Presented at: 42nd Congress of Vine and Wine 17th General Assembly of the OIV; 2019 July 15th-19; CICG, Geneva, Switzerland.

[20] Jones G. Climate change in the western United States grape growing regions. Brussels, Belgium, Acta Hortic;2005.

[21] Gladstones J. Viticulture Volume 1 - Resources. Dry PR, Coombe BG, editors. Adelaide:Winetitles; 2004.Climate and Australian viticulture.

[22] Ostroukhova E, Levchenko S, Vasylyk I, Volynkin V, Lutkova N, Boyko V?. Comparison of the phenolic complex of crimean autochthonous and classic white-berry grape cultivars. International Conference on Efficient Production and Processing; Prague, Czech Republic, February 27-28, 2020

[23] Dikan ?P, Vilchinskiy VF, Vernovskiy E?, Zayats IY. Viticulture of the Crimea.Simferopol: Biznes-Inform; 2001.

[24] Huglin, P. (1978) Nouveau mode d'évaluation des possibilités héliothermiques d'un milieu viticole. Comptes Rendus de l'Académie d'Agriculture de France, 1978, 64, 1117-1126.

[25] Amerine MA, WinklerAJ.Composition and quality of musts and wines of California grapes. Hilgardia.1944;15(6):493-673.

[26] Selyaninov GT. On the agricultural assessment of climate. Proceedings on Agriculture Meteorology. 1928; 20. 165-177

[27] Rybalko EA. Adaptation of mathematical model of spatial distribution of warm temperatures supply of territory for the purpose of effective placing of industrial vineyards in territory of the Crimean peninsula. Viticulture and Winemaking.2014;2:10-11.

[28] Rybalko EA, Baranova NV.Development of a simulation model of frost susceptibility spatial distribution on the territory of the Republic of Crimea as applied to viniculture. Environmental Control Systems. 2016;6(26):101-105.

[29] Rybalko EA, Baranova NV, Borisova VY.Patterns of the spatial variation of Huglin index in the conditions of the Crimean Peninsula. Winemaking and Viticulture. 2020;1:18-23.

[30] Rybalko EA, Baranova NV, Borisova VY.Study of laws of spatial variation of the mean air temperature for the growing season on the territory of the Crimean Peninsula.Magarach, Viticulture and Winemaking. 2020;2:120-124. 
[31] Ed VG. Gerzhikova metody techno-chemical control methods in winemaking. $2^{\text {nd }}$ edition. Simferopol: Tavrida Publ; 2009.

[32] Mehuzla NA. Collection of international methods for the analysis and evaluation of wines and wort. Moscow; Food Industry, 1993.

[33] Yermakov Al.Methods of biochemical research of plants. $2^{\text {nd }}$ edition. Leningrad: KolosPubl.; 1972.

[34] Rybalko EA, Baranova NV. Trends analysis of changes in the climatic conditions of the Republic of Crimea for advanced mapping of locations suitable for vineyards establishment. Environmental Control Systems. 2018;14(34):116-121.

[35] Raul F-G, Hernandez-Hierro JM, Rivas-Gonzalo JC, Escribano-Bailon MT. Influence of climatic conditions on the phenolic composition of Vitis vinifera L. CV. Graciano.Analytica Chimica Acta. 2012;732:73-77.

[36] Spayd SE, Tarara JM, Mee DL, Ferguson JC. Separation of sunlight and temperature effects on the composition of vitis vinifera cv. Merlot Berries. American Journal of Enology and Viticulture. 2002;53:171-182.

[37] Ostroukhova EV, Peskova IV, Rybalko EA, Tvardovskaya LB.The effect of climatic factors on the technological characteristics of red grape varieties cultivated in different regions of the republic of the ?rimea. Magarach. Viticulture and Winemaking. 2015;2:28-31.

[38] He F, Mu L, Yan GL et al. Biosynthesis of anthocyanins and their regulation in colored grapes. Molecules.2010;15:9057-9091.

[39] MarkosovVA, Ageeva NM. Biochemistry, technology and biomedical features of red wines. Krasnodar: North-caucasian zone research institute of horticulture and viticulture; 2008.

[40] Rio P, KennedyJ, KennedyJA.Development of proanthocyanidins in Vitis vinifera L. cv. Pinot noir grapes and extraction into wine. American Journal of Enology and Viticulture. 2006;57:125-132.

[41] Gil-MunozR, Gomez-Plaza E,MartmnezA et al.Evolution of phenolic compounds during wine fermentation and post-fermentation: Influence of grape temperature. Journal of Food Composition and Analysis. 1999;12:259-272.

[42] Ostroukhova EV.The dynamics of grapevine oxidase activity during skin contact and its role in the formation of the must phenol complex. Viticulture and Winemaking. 2011;2:16-18. 